\title{
Brief Communication Analysis of Brazilian Presidency during COVID-19
}

Leaders with a full understanding of their responsibilities make use of strategic communication and their credibility to reduce uncertainties in times of crisis

Brazilians are torn between believing the information coming from the president or following the instructions of their governors. The president has been asking the population to return to normalcy. Governors, however, call on the population to continue in isolation at home in order to reduce the rate of community transmission of the new coronavirus. The purpose of this article is to understand the reasons that led to this predicament through a review of public statements made by the current Brazilian president from the beginning of the global COVID-19 crisis to the present moment. For this analysis, this article resorts to the theoretical framework developed by professor Arjen Boin and his co-authors in 'The Politics of Crisis Management'.

After the Chinese government announced and enforced mandatory quarantine in Wuhan as a measure to contain the spread of the new coronavirus, the Brazilian president's first reaction was to rule out the possibility of 'rescuing' the country's citizens claiming the government did not have enough resources ${ }^{2}$ to carry out such an operation. Days after the confirmation of the first official report for an individual infected by the new coronavirus in the country, the president minimized the severity ${ }^{3}$ of this respiratory disease. After the exponential growth of cases across the country and state governors deciding to restrict the movement of people, the president launches a campaign ${ }^{4}$ asking Brazilians to leave their homes on the grounds that responsibility for preventing the spread of this virus among the most vulnerable is up to families ${ }^{5}$ and not the state. At the present time, the Brazilian society is unsure whether they should follow the president's requests or local authorities' recommendations.

\footnotetext{
${ }^{1}$ Boin, A., Stern, E. and Sundelius, B., 2016. The politics of crisis management: Public leadership under pressure. Cambridge University Press.

2 Globo 2020, Bolsonaro diz que não traz brasileiros da China porque 'custa caro' e não há lei de quarentena, Globo.com, viewed 1 April 2020

<https://g1.globo.com/politica/noticia/2020/01/31/bolsonaro-reune-ministros-para-avaliar-risco-do-coronav irus-e-situacao-de-brasileiros-na-china.ghtml>

${ }^{3}$ Benites, A., Betim, F., 2020. Bolsonaro rompe isolamento e vai a atos contra o Congresso em meio à crise do coronavírus, El País, viewed 1 April 2020

$<$ https://brasil.elpais.com/brasil/2020-03-15/bolsonaro-rompe-isolamento-e-endossa-atos-contra-congres so-em-meio-a-crise-do-coronavirus.html>

${ }^{4}$ DW 2020. Justiça suspende campanha "O Brasil não pode parar", DW, viewed 1 April 2020 $<$ https://www.dw.com/pt-br/justi\%C3\%A7a-suspende-campanha-o-brasil-n\%C3\%A3o-pode-parar/a-5294 $\underline{8560>}$

${ }^{5}$ Barrucho, L., 2020. Coronavírus: os dados que põem em xeque ideia de Bolsonaro de isolar idosos, BBC, viewed 1 April 2020 <https://www.bbc.com/portuguese/geral-52043354>
} 
Arjen Boin, an expert in crisis management, gives us a solid theoretical background for the assessment of the current political scenario. Boin explains that in times of crisis, people look up to authorities for information on how to proceed. These authorities reduce anxiety explaining to the population i) what is going on, ii) the reasons for so much uncertainty and iii) what needs to be done. These are the elements that substantiates strategic political communication in times of crisis. If officials fail in one of these aspects, their political decisions risk not being widely accepted. As a result, other voices are given the opportunity to interpret facts and suggest alternatives. It is in this imbroglio that Brazilians are immersed in: who to believe in?

Politicians that master strategic communication can effectively reverse the snowballing effects of crises. This effort, however, depends on authorities' credibility. This leads to the review of how authorities gain or lose trust placed upon them. Reputation is the first source that determines the credibility of a leader's messages. If society respects a particular leader, they are more likely to interpret verbal and nonverbal cues and, as a result, comply with determinations. The second source from which authorities derive credibility is how they initially respond to an unfolding crisis. If, for example, an authority minimizes its risks at first, that action will serve as a benchmark to assess the next political moves. Authorities also need to calculate the timing to respond to crises. If public response is too slow, opportunities for other communication channels are opened. If it is too fast, it can be interpreted as a lack of due diligence.

The theory developed by Boin and his colleagues has served in the training of authorities around the world. They point to Jacinda Arden ${ }^{6}$, the current Prime Minister of New Zealand, as a political figure who masters crisis management communication techniques because she clearly understands a leader's priorities in times of great uncertainty. Among them: the protection of the most vulnerable segments of society. This understanding, however, which serves as a premise for the theory of Boin and his colleagues, has been repeatedly violated by the current Brazilian president.

\footnotetext{
61 News 2020, 'Yes we can' - Jacinda Ardern confident New Zealand can beat coronavirus pandemic, 1 News, viewed 1 April 2020 $<$ https://www.tvnz.co.nz/one-news/new-zealand/yes-we-can-jacinda-ardern-confident-new-zealand-beat-c oronavirus-pandemic $>$
} 